\title{
MATHEMATICAL MODEL DESCRIBING THE COURSE OF THE PROCESS OF WEAR OF A HOB CUTTER FOR VARIOUS METHODS OF CUTTING FLUID SUPPLY
}

\section{MODEL MATEMATYCZNY OPISUJĄCY PRZEBIEG ZUŻYCIA FREZU ŚLIMAKOWEGO DLA RÓŻNYCH METOD PODAWANIA CIECZY OBRÓBKOWEJ*}

\begin{abstract}
In the paper the method of determining the mathematical relationship for calculating the flank wear VB $B_{c}$ of the most worn hob tooth is discussed. The relationship, in the form of a multiple regression function, was determined based on the acceptance and rejection method. The data for the calculations was obtained from experiments carried out for hobbing of carbon steel C45 with the use of a cutting fluid supplied in flood mode (WM) and with a minimum quantity lubrication mode (MQL). Based on the developed equations the impact of the selected machining parameters the course of the hob wear was assessed. In the final part of the paper, the obtained mathematical relationships were analysed and verified.
\end{abstract}

Keywords: hobbing, hob, wear, cutting fluid, $M Q L$.

\begin{abstract}
$W$ artykule omówiono metodę wyznaczania zależności matematycznej do obliczania wielkości starcia VB $B_{c}$ najbardziej zużytego ostrza frezu ślimakowego. Zależność w postaci funkcji regresji wielorakiej wyznaczono metoda dołaczania i odrzucania. Dane do obliczeń uzyskano przeprowadzając badania eksperymentalne frezowania stali węglowej C45 z udziałem cieczy obróbkowej podawanej w trybie obfitym oraz z minimalnym wydatkiem (MQL). W oparciu o wyznaczone równania dokonano oceny wplywu wybranych warunków obróbki na przebieg zużycia frezów ślimakowych. W końcowej części artykułu dokonano analizy uzyskanych zależności matematycznych oraz przeprowadzono ich weryfikacje.
\end{abstract}

Slowa kluczowe: frezowanie obwiedniowe, frez ślimakowy, zużycie, ciecz obróbkowa, $M Q L$.

\section{Introduction}

The gears machining, with the application of a cutting fluid supplied with a minimum flow rates (MQL - Minimum Quantity Lubrication) is a technology still under development. However, in industrial applications, it is still a novelty. This concerns, among other manufacturing processes, hobbing which is the most popular method of machining gears. In this method, the allowance is removed by many cutting teeth distributed on the hob circumference. In the gear hobbing, cutting teeth are unevenly loaded and this results in uneven wear distribution on particular hob teeth. Out of the total number of hob teeth, only a part of them remove work material, and only few of them present maximum wear land [3]. In practice, when tool wear reach critical values even at one hob tooth the hob is regarded as dull.

The available literature concerned the hobbing process shows that the impact of the application of the MQL method on the effectiveness of this process has not been investigated yet or it concerns a limited scope only [5]. In the research described in the literature [16, 17] it was shown that the use of this method in some circumstances enables to obtain the results comparable to the conventional method of the cutting fluid supply and much better than those obtained for "dry machining". However, the results and conclusions drawn from those studies could be misleading because research was carried out for a single-tooth tool (the so-called "fly tool") instead hobbing.

The basis for assessing the effectiveness of various methods of the cutting fluid supply are the courses of the tool wear in the entire hob tool life. Therefore, the effectiveness of lubrication and/or cooling in the MQL method can be determined by comparing the courses of hob wear with those obtained for hobbing with flood supply of cutting fluid (WM - Wet Machining).

It should be taken into consideration, that the tool being worn is the weakest item in machining systems. Therefore, the possibility to predict the tool wear rates in various cutting conditions is of particular importance, especially to minimize the cost- and time-consuming durability investigations. In order to predict tool wear, appropriate mathematical procedures can be used, e.g. the method of trend analysis [8], artificial neural networks [9], fuzzy logic modelling based on the TSK structure [10], or the model of a second degree equation that predicts the durability of the hob by using the surface response method [13].

In various research centres, investigations on the hob teeth wear process were undertaken. In the study [6] a method to determine the variable load of the active cutting edges was proposed, by application of a tool in the form of a rack (flute hobbing), which is the progress in relation to the method of using a single-tooth tool [3]. In [7] it was indicated that for tools with TiN coating, application of the MQL method causes less intensive tool wear rates when compared with those obtained for uncoated tools. Another problem undertaken in the study [18] is to determine the cutting edge condition's impact on the wear rate during hobbing without any cutting fluid (DM - Dry Machining). As part of the research studies $[2,4]$ the mathematical description of the hob wear changes was also proposed. In those studies the mathematical description is based mainly on the analysis of the load variations on the active cutting edges during machining, resulting from the

(*) Tekst artykułu w polskiej wersji językowej dostępny w elektronicznym wydaniu kwartalnika na stronie www.ein.org.pl 
variable chip cross-section areas in different angular positions of the hob in relation to the gear being machined.

In the paper, the method to determine the mathematical relationship for the calculation of the flank wear land width $V B$ of the most worn hob tooth is discussed. The data necessary to evaluate equation parameters was obtained from experimental investigations. The relationship, in the form of the multiple regression function, were determined by means of the acceptance and rejection method algorithm. Then, based on power polynomial equations, the impact of the selected machining conditions (cutting speed, feed, the cutting fluid supply method) on the courses of the hob wear rates as well as on cutting forces was assessed.

\section{Experiments}

The aim of the experimental investigations was to collect data concerning the hob wear rates and the cutting forces in gear hobbing:

- with the supply of cutting fluid in a flood mode (WM)

- with the minimum quantity lubrication mode (MQL).

In the investigations, various machining parameters were applied (cutting speed, feed), and the values $V B_{c}$ were measured (no vital wear was observed on the rake face) as well as the corresponding cutting forces $F_{c}$. Those data were selected just because they have a considerable impact on the tool wear process. The previous investigations of the gear hobbing, e.g. [11], proved that among all the cutting parameters the cutting speed $v_{c}$ has the greatest impact on tool wear. The main reason for that is that cutting speed determines, to the greatest extent, the cutting temperature. This was confirmed by other researchers, e.g. [1]. On the other hand, the cutting force can be used as an indirect measure of hob wear magnitude. This is because the wear of hob leads, during the machining process, to the change of the cutting conditions, which in turn leads to an increase of cutting forces. Also deterioration of the quality of the workpiece being machined can be observed.

\subsection{Durability tests}

Durability tests were carried out for hobbing of spur gears made of carbon steel C45 (20 \pm 2 HRC). The blanks to machine gears had an outer diameter of $d=72 \mathrm{~mm}$ and a width of $b=15 \mathrm{~mm}$. Using the ZFC-20 hobbing machine involute teeth of module $m=3 \mathrm{~mm}$, pressure angle $\alpha=20^{\circ}$, and tooth inclination angle $\beta=0^{\circ}$, were cut. The NMFc$3 / 20^{\circ} / \mathrm{B}$ gear-cutting hobs made of high-speed steel HS6-5-2 without any coatings were used. The cutting fluid Ferokol EP machine oil was applied for wet machining with a flow rate of about $10 \mathrm{l} / \mathrm{h}$. For MQL the MKS-G100 device was applied with an external single-channel generation of oil mist with flow rate of $15 \mathrm{ml} / \mathrm{h}$. The investigations were carried out for different cutting parameters (Table 1) with a constant hobbing path $L=400 \mathrm{~mm}$.

The gears being machined were fastened on a specially designed mandrel intended for fixing a single-component piezoelectric dynamometer KISTLER, type $9321 \mathrm{~B}$, enabling the cutting force $F_{c}$ to be measured. The measuring signal from the dynamometer was directed to the single-channel laboratory amplifier KISTLER, type 5011B, and converted into a voltage signal. Next, the signal from the amplifier

Table 1. Cutting parameters.

\begin{tabular}{||c|c|c||}
\hline \multicolumn{3}{|c||}{ Cutting parameters } \\
\hline $\begin{array}{c}\text { cutting speed } \\
v_{c}[\mathrm{~m} / \mathrm{min}]\end{array}$ & $\begin{array}{c}\text { feed } \\
f[\mathrm{~mm} / \mathrm{rev}]\end{array}$ & $\begin{array}{c}\text { depth of cut } \\
a_{p}[\mathrm{~mm}]\end{array}$ \\
\hline 34,4 & & \\
44,2 & 0,50 & 6,6 \\
54,0 & 1,25 & \\
69,9 & & \\
\hline
\end{tabular}

was sent to the measuring card KEITHLEY, type KPCMCIA-12AI-C installed in the computer. The software for the recording the measurement data was developed in the Institute of Machine Tools and Production Engineering of the Lodz University of Technology and described in details in [20].

In Fig. 1 an example of the graph of the cutting force course obtained during the gear hobbing was presented. It can be seen that due to the variable number of the hob teeth cutting simultaneously during one hob revolution the total chip cross-section varies. This affects, in turn, the cutting force magnitude.

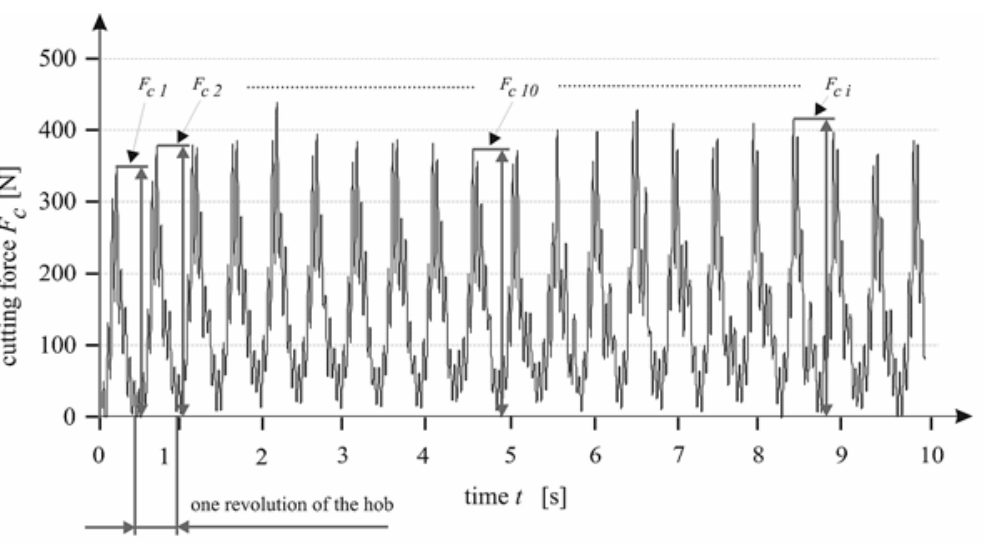

Fig. 1. Example of cutting force vs. time relationship.

The 10 seconds duration of the measurement cutting forces was set. At that time the hob was running at about 20 revolutions. As the result of particular test as a cutting force measurement result, the average value of the maximum cutting forces peaks $F_{c}$ " $i$ " (where " $\mathrm{i}$ " is the successive number of the hob cutter revolution) observed for each revolution of the hob was taken.

An optical microscope was used to measure the hob teeth wear lands. The wear of the hob teeth was observed on the flank surfaces as a wear lands unevenly distributed along cutting edges. The highest value of the wear land width $V B_{c-i n}$ was observed in the vicinity of the tooth corner area on the side entering tooth space. This value, for the most worn tooth, was taken as a measure of hob wear during the analysis of the investigation results.

\subsection{Determination of mathematical relationship}

To determine the mathematical relationships for the calculation of tool wear, the original SKZ software was developed in the Institute of Machine Tools and Production Engineering of the Lodz University of Technology [14]. The SKZ software makes it possible to determine the coefficients of a multiple regression equation. The procedure for regression analysis was developed on the basis of the algorithm of the acceptance and rejection method described in the paper [15].

The procedure of the software application began with entering input data $\left(v_{c}, f, F_{c}\right)$ from a text file prepared earlier, and selecting the form of the regression function $(\mathrm{Y} 1=\mathrm{B} 0+\mathrm{Sum}(\mathrm{Bi} * \mathrm{Xi}))$. Since the durability tests were carried out for a constant depth of cut $a_{p}$, this parameter was not taken into consideration.

The selection of the critical statistics values $\left(F_{k r}\right)$ is made on the significance level $\alpha=0,4$, and after having the regression function determined it is changed into the value of $\alpha=0,1$. The calculations began with the simplest regression function, and new elements are attached (accepted) successively. If a newly attached element lowers the significance of an element that has already been introduced, the irrelevant element is removed from the regression function. After having introduced all the relevant elements a preview panel with the calculation results is displayed. Finally, the function of the object investigated took on the form shown below: 


$$
V B_{c-i n}=V B_{0} \cdot v_{c}^{f_{v}} \cdot f^{f_{f}} F_{c}^{f_{F}}[\mathrm{~mm}]
$$

where: $v_{c}-[\mathrm{m} / \mathrm{min}] ; f-[\mathrm{mm} / \mathrm{rev}] ; F_{c}-[\mathrm{N}]$.

The values of the coefficients and constants of this function determined on the basis of calculations are listed in Table 2.

Table 2. Values of constants and coefficients for experimental function

\begin{tabular}{|c|c||}
\hline \multicolumn{2}{|c||}{ Constants and coefficients } \\
\hline WM & MQL \\
\hline$V B_{0}=9,98 \cdot 10^{-21}$ & $V B_{0}=2,15 \cdot 10^{-12}$ \\
$f_{V}=-2,194$ & $f_{V}=-1,569$ \\
$f_{f}=-0,633$ & $f_{f}=-0,604$ \\
$f_{F}=8,962$ & $f_{F}=5,282$ \\
\hline Coefficient of multiple correlation $R$ \\
\hline 0,7502 & 0,7418 \\
\hline
\end{tabular}

After entering the numerical values from Table 2 into the function of the object of investigation (1) the following equations were obtained:

- for the supply of cutting fluid in the flood mode (WM):

$$
V B_{c-\text { in }}=9,98 \cdot 10^{-21} \cdot v_{c}^{-2,194} \cdot f^{-0,633} \cdot F_{c}^{8,962}[\mathrm{~N}]
$$

- the MQL method:

$$
V B_{c-i n}=2,15 \cdot 10^{-12} \cdot v_{c}^{-1,569} \cdot f^{-0,604} \cdot F_{c}^{5,282}[\mathrm{~N}] .
$$

\section{Analysis of the relationships obtained}

The significance of the coefficients obtained for the multiple correlation $R$ were determined by means of the Fisher-Snedecor $F$ test through the calculation of the $F$ coefficient test values and comparing them with the critical values $F_{k r}$. Because the calculations showed the relation $F>F_{k r}$, the correlation coefficients should be regarded as relevant, and this means the conformity (at the significance level of $\alpha=0,1)$ of the regression equation with the investigation's results [12].

The analysis of the constants and the exponents presented in Table 2 indicates that those values differ, depending on the cutting fluid supply method applied. This concerns both the $V B_{0}$ constants which generally define the wear rate level, and the exponents determining the impact of the individual machining conditions on the changes of the wear rate.

The highest differences were observed when comparing the $f_{F}$ and $f_{v}$ exponents for the MQL method with the exponents obtained for the WM mode. The values of the $f_{v}$ exponents differ by almost $40 \%$, whereas the $f_{F}$ exponents differs by $70 \%$. This indicates that with the cutting fluid supply in the flood mode (WM) the $V B_{c-i n}$ wear sensitivity for the $v_{c}$ changes of cutting speed is much higher when compared to MQL. The same relationship concerns the cutting forces $F_{c}$ that changes according to the hob wear magnitude.

For the $f_{f}$ coefficients no significant differences in their values were observed ( $-0,633$ and $-0,604$ respectively). This shows that the impact of the feed $f$ on the wear rate is similar, regardless of the cutting fluid supply method. It is worth to point out that this situation could be caused by the fact that the longitudinal feed is a relevant parameter influencing the maximum value $F_{c}$ of cutting force [19] and as such it is already considered in the $f_{F}$ coefficient.
The illustration that presents the impact of the $v_{c}$ and $F$ parameters, dependent mostly on the cutting fluid supply method, on the hob wear $V B_{c-i n}$ is shown in Fig.3. The graphs are presented for the feed $f=0,5 \mathrm{~mm} / \mathrm{rev}$. The graphs for the feed $f=1,25 \mathrm{~mm} / \mathrm{rev}$ are of a similar nature. The surfaces on the graph present the hob wear rate levels to be expected depending on variable cutting conditions.

As it results from Fig. 3 and the relationships (2) and (3) the application of higher cutting speed $v_{c}$ leads to the conclusion that in any case when the assumed criterial wear $V B_{c-k r}$ is achieved higher $F_{c}$ cutting forces were observed. This is confirmed by the values listed in Table 3.

It should be noted that for the flood cutting fluid supply mode (WM) the increase in cutting speed (in particular to $v_{c}=54 \mathrm{~m} / \mathrm{min}$ and $v_{c}=69,9 \mathrm{~m} / \mathrm{min}$ ) results in lower forces $F_{c}$ occured in relation to that observed in the case of the MQL application. For the hob wear equal to $0,3 \mathrm{~mm}$ the difference between the cutting forces for lowest and highest cutting speeds is $64 \mathrm{~N}$, whereas for the MQL method amounts to $80 \mathrm{~N}$. Similarly, for the hob wear of $0,5 \mathrm{~mm}$ the difference between the cutting forces for the lowest and highest cutting speeds is $68 \mathrm{~N}$, whereas for the MQL method amounts to $88 \mathrm{~N}$. This confirms the previous observations concerning the higher wear sensitivity $V B_{c-i n}$ to the changes of the cutting speed $v_{c}$ and the cutting force $F_{c}$ for "wet cutting" (WM) when compared to the MQL method.

a)

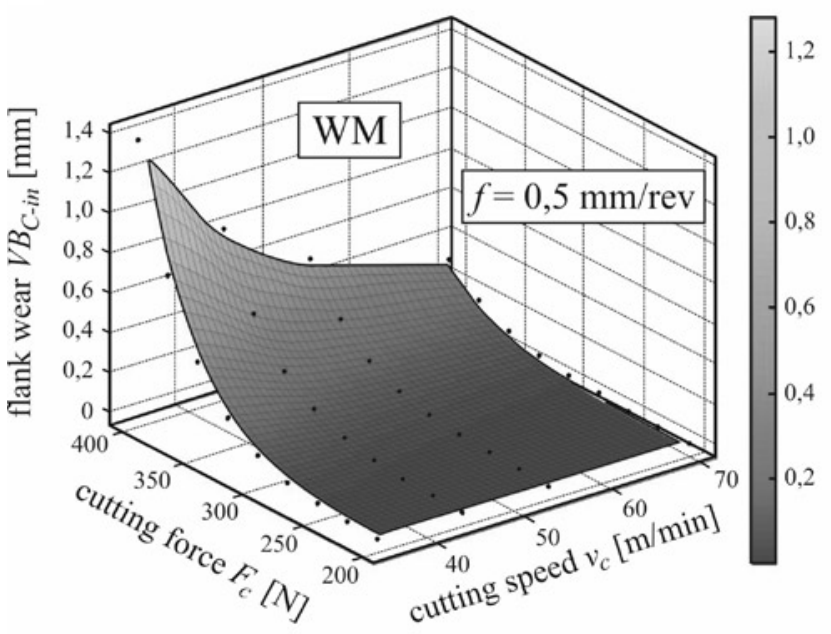

b)

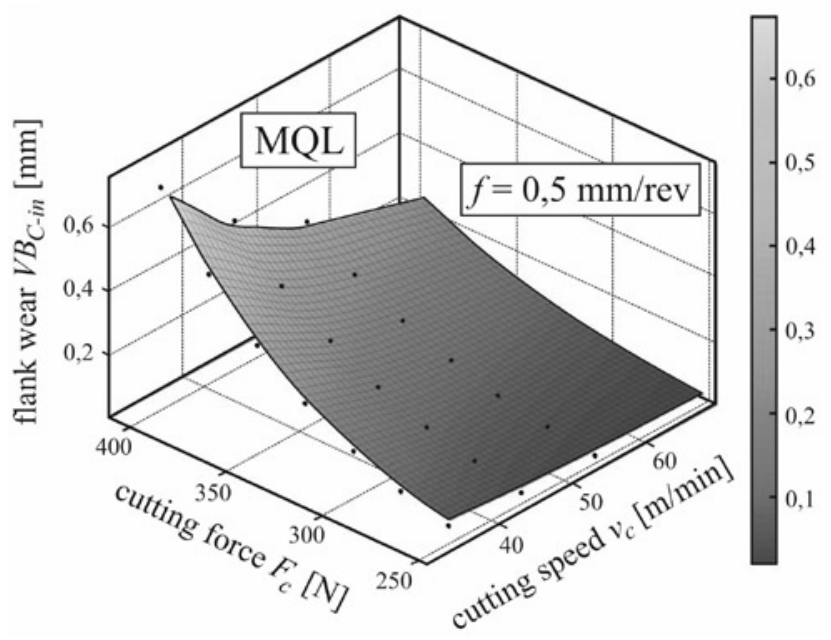

Fig. 2. Influence of cutting force and cutting speed on hob's flank wear: a) $W M$, b) $M Q L ; f=0,5 \mathrm{~mm} / \mathrm{rev}$ 
Table 3. Cutting force values for the critical flank wear

\begin{tabular}{|c|c|c|c|c|}
\hline \multirow{2}{*}{$\begin{array}{c}f \\
{[\mathrm{~mm} / \mathrm{rev}]}\end{array}$} & \multirow{2}{*}{$\begin{array}{l}V B_{c-k r} \\
{[\mathrm{~mm}]}\end{array}$} & \multirow{2}{*}{$\begin{array}{c}v_{c} \\
{[\mathrm{~m} / \mathrm{min}]}\end{array}$} & WM & MQL \\
\hline & & & \multicolumn{2}{|c|}{$F_{c}[\mathrm{~N}]$} \\
\hline \multirow{8}{*}{0,5} & \multirow{4}{*}{0,3} & 34,4 & 338 & 340 \\
\hline & & 44,4 & 359 & 367 \\
\hline & & 54,0 & 377 & 389 \\
\hline & & 69,9 & 402 & 420 \\
\hline & \multirow{4}{*}{0,5} & 34,4 & 357 & 375 \\
\hline & & 44,4 & 380 & 404 \\
\hline & & 54,0 & 399 & 429 \\
\hline & & 69,9 & 425 & 463 \\
\hline
\end{tabular}

\section{Verification of the mathematical model}

In spite of the satisfactory values of the multiple correlation coefficients for the developed mathematical model its verification was also carried out consisting of a comparison of the measured wear values $V B_{c-i n}$ with the values calculated on the basis of this model.

In Fig. 4 the comparison of the calculated and measured wear values $V B_{c-i n}$ while hobbing gears with the cutting fluid supply in the flood mode (Fig. 4a) and the minimum quantity lubrication mode (Fig. 4b) is presented. The graphs were made for constant cutting parameters: $v_{c}=69,9 \mathrm{~m} / \mathrm{min}, f=0.5 \mathrm{~mm} / \mathrm{rev}, a_{p}=6,6 \mathrm{~mm}$.

a)

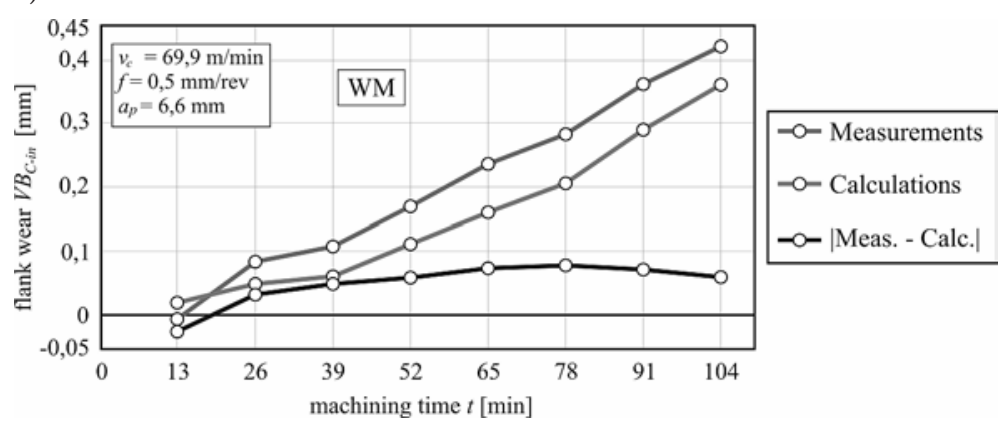

b)

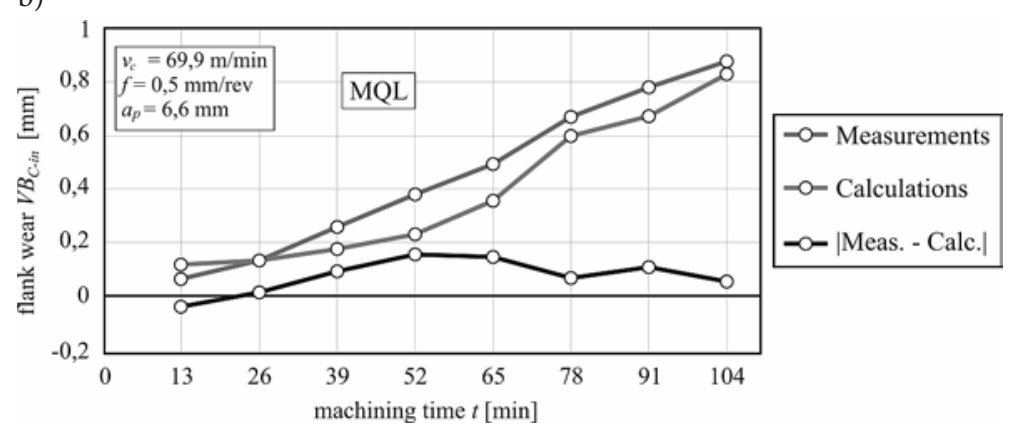

Fig. 3. Comparison of calculated results to measured values of flank wear $V B_{c-i n}$ : a) $W M$, b) $M Q L ; v_{c}=69,9 \mathrm{~m} / \mathrm{min}, f=0,5 \mathrm{~mm} / \mathrm{rev}, a_{p}=6,6 \mathrm{~mm}$.
The differences between the calculated and measured wear rates vary within the range from $0,03 \mathrm{~mm}$ up to $0,08 \mathrm{~mm}$ for the hobbing with the flood cutting fluid supply method (WM) and in the range from 0,02 up to $0,12 \mathrm{~mm}$ for the hobbing with the MQL method. It should be noted that for both methods the differences decrease as the machining time increases. For the WM method in the final stage of the diagram the difference amounts to $14 \%$, and for the MQL method it drops to $6 \%$. In both cases, the hob wear vs. time diagrams drawn on the basis of calculations run below the experimental ones.

Similar hob wear diagrams for both the measured as well as the calculated values were also obtained in other tests. This proves the correctness of the developed model.

\section{Conclusions}

The aim of this study was to evaluate the mathematical relationships enabling a prediction of the flank wear $V B_{c}$ of the most worn out hobbing tooth. The possibility to predict tool wear is a relevant factor affecting the correct planning of the gear machining process when using the hobbing method. Based on an analysis of the obtained results the following conclusions have been drawn:

1. A mathematical model has been developed in the form of a multiple regression function which enabled a calculation of the $V B_{c-\text { in }}$ wear rate for the most worn tooth.

2. The acceptance and rejection method used for working out the model is relatively easy to apply with the use of appropriate software.

3. With a continuous measurement of cutting forces, it is possible to monitor the state of hob wear during machining.

4. Experimental verification of the obtained relationships have proved their correctness for both cutting fluid supply methods (WM and MQL).

5. The model developed creates a good basis for the analysis of the hobbing gear process. Thanks to the determined mathematical relationships it is possible to avoid labor-, and timeconsuming experimental studies.

Based on the work performed and the obtained results it should otherwise be noted that:

1. The analysis of the exponents determining the impact of machining conditions on the wear rate has shown that the cutting speed $v_{c}$ and the cutting force $F_{c}$ are the parameters most sensitive to the cutting fluid supply method (WM, MQL).

2. For the cutting fluid supply in the flood mode (WM) higher wear sensitivity to the cutting speed changes $v_{c}$ occurs when compared with the MQL method. The same relationship concerns the cutting forces $F$ accompanying the hob wear process.

3. The impact of the feed $f$ on the wear rate does not depend on the cutting fluid supply method.

4. The application of the MQL method in in presented experiments was only possible as an external supply of cutting fluid to the cutting zone. It seems that the supply of oil mist directly to the cutting zone through the tool would improve cutting conditions and slow down the process of tool wear. This should be the objective of further works and experimental studies.

\section{References}

1. Azizpour Jalali M., Majd Mohammadi H. Wear mechanisms in high speed steel gear cutting tools. World Academy of Science, Engineering and Technology 2010; 4: 739-741.

2. Belis T., Antoniadis A. Hobbing wear prediction model based on 3D chips determination. Bulletin of the Polytechnic Institute of Iasi 2010; LXI(LX) 2: 9-20. 
3. Bouzakis K.-D., Kombogiannis S., Antoniadis A., Vidakis N. Gear hobbing cutting process simulation and tool wear prediction models. Journal of Manufacturing Science and Engineering 2001; 124(1): 42-51, http://dx.doi.org/10.1115/1.1430236.

4. Bouzakis K.-D., Lili E., Michalidis N., Friderikos O. Manufacturing of cylindrical gears by generating cutting processes: A critical synthesis of analysis methods. CIRP Annals - Manufacturing Technology 2008; 57: 676-696, http://dx.doi.org/10.1016/j.cirp.2008.09.001.

5. Byrne G., Dornfeld D., Denkena B. Advancing cutting technology. CIRP Annals - Manufacturing Technology 2003; 52/2: $483-507$.

6. Claudin C., Rech J. Development of a new rapid characterization method of hob's wear resistance in gear manufacturing-Application to the evaluation of various cutting edge preparations in high speed dry gear hobbing. Journal of Materials Processing Technology 2009; 209: 5152-5160, http://dx.doi.org/10.1016/j.jmatprotec.2009.02.014.

7. Fratila D. Evaluation of near-dry machining effects on gear milling process efficiency. Journal of Cleaner Production 2009; 17: 839-845, http://dx.doi.org/10.1016/j.jclepro.2008.12.010.

8. Gawlik J., Karbowski K. Matematyczne modelowanie procesu zużycia narzędzi skrawających-Nadzorowanie stanu narzędzi. Kraków: Politechnika Krakowska, Monografia 231, seria Mechanika, 1998.

9. Grzesik W. Podstawy skrawania materiałów konstrukcyjnych. Warszawa: WNT, 2010.

10. Ren Q., Balazinski M., Baron L., Jemielniak K. TSK fuzzy modeling for tool wear condition in turning processes: An experimental study. Engineering Applications of Artificial Intelligence 2011; 24/2: 260-265, http://dx.doi.org/10.1016/j.engappai.2010.10.016.

11. Kiepuszewski B., Legutko S., Wieczorowski K. Skrawanie metali. Poznań: Wydawnictwo Politechniki Poznańskiej, 1980.

12. Korzyński M. Metodyka eksperymentu-Planowanie, realizacja i statystyczne opracowanie wyników eksperymentów technologicznych. Warszawa: WNT, 2013.

13. Królczyk G., Gajek M., Legutko S. Predicting the tool life in the dry machining of duplex stainless steel. Eksploatacja i Niezawodnosc -Maintenance and Reliability 2013; 15 (1): 62-65.

14. Kruszyński B., Midera S., Kaczmarek J. Forces in generating gear grinding-theoretical and experimental approach. CIRP Annals Manufacturing Technology 1998; 47: 287-290, http://dx.doi.org/10.1016/S0007-8506(07)62835-2.

15. Mańczak K. Technika planowania eksperymentu. Warszawa: WNT, 1976.

16. Matsuoka H., Tsuda Y., Suda S., Yokota H. Fundamental research on hobbing with minimal quantity lubrication of cutting oil (effect of quantity of oil supply). JSME International Journal 2006; C 49/2: 590-599.

17. Matsuoka H., Tsuda Y., Suda S., Yokota H. Fundamental research on hobbing with minimal quantity lubrication of cutting oil (effect of cutting speed). JSME International Journal 2006; C 49/4: 1140-1150.

18. Rech J. Influence of cutting edge preparation on the wear resistance in high speed dry gear hobbing. Wear 2006; 261: 505-512, http://dx.doi. org/10.1016/j.wear.2005.12.007.

19. Stachurski W. Wpływ warunków podawania cieczy obróbkowej w strefę skrawania z minimalnym wydatkiem na zużycie frezu ślimakowego. Łódź: Praca doktorska, 2008.

20. Stachurski W. Application of minimal quantity lubrication in gear hobbing. Mechanics and Mechanical Engineering 2012; 16/2: 133-140.

Wojciech STACHURSKI

Stanisław MIDERA

Bogdan KRUSZYŃSKI

Institute of Machine Tools and Production Engineering

Lodz University of Technology

ul. Stefanowskiego 1/15, 90-924 Łódź, Poland

E-mail: wojciech.stachurski@p.lodz.pl, stanislaw.midera@p.lodz.pl, bogdan.kruszynski@p.lodz.pl 